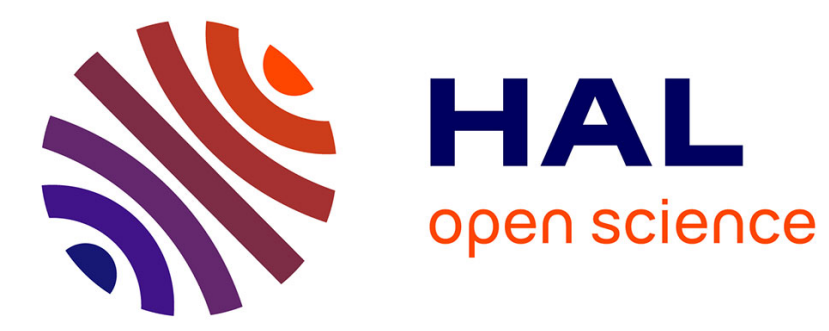

\title{
The permissive role of prolactin as a regulator of luteinizing hormone action in the female mouse ovary and extragonadal tumorigenesis
}

Anne Bachelot, Nadège Carré, Olivier Mialon, Melody Matelot, Nathalie Servel, Philippe Monget, Petteri Ahtiainen, Ilpo Huhtaniemi, Nadine Binart

\section{To cite this version:}

Anne Bachelot, Nadège Carré, Olivier Mialon, Melody Matelot, Nathalie Servel, et al.. The permissive role of prolactin as a regulator of luteinizing hormone action in the female mouse ovary and extragonadal tumorigenesis. AJP - Endocrinology and Metabolism, 2013, 305 (7), pp.E845-E852. 10.1152/ajpendo.00243.2013 . hal-01129773

\section{HAL Id: hal-01129773 \\ https://hal.science/hal-01129773}

Submitted on 29 May 2020

HAL is a multi-disciplinary open access archive for the deposit and dissemination of scientific research documents, whether they are published or not. The documents may come from teaching and research institutions in France or abroad, or from public or private research centers.
L'archive ouverte pluridisciplinaire HAL, est destinée au dépôt et à la diffusion de documents scientifiques de niveau recherche, publiés ou non, émanant des établissements d'enseignement et de recherche français ou étrangers, des laboratoires publics ou privés. 


\section{The permissive role of prolactin as a regulator of luteinizing hormone action in the female mouse ovary and extragonadal tumorigenesis Anne Bachelot, Nadège Carré, Olivier Mialon, Melody Matelot, Nathalie Servel, Philippe Monget, Petteri Ahtiainen, Ilpo Huhtaniemi and Nadine Binart \\ Am J Physiol Endocrinol Metab 305:E845-E852, 2013. First published 6 August 2013; doi:10.1152/ajpendo.00243.2013}

You might find this additional info useful...

This article cites 45 articles, 27 of which can be accessed free at: /content/305/7/E845.full.html\#ref-list-1

Updated information and services including high resolution figures, can be found at: /content/305/7/E845.full.html

Additional material and information about AJP - Endocrinology and Metabolism can be found at: http://www.the-aps.org/publications/ajpendo

This information is current as of October 24, 2013. 


\title{
The permissive role of prolactin as a regulator of luteinizing hormone action in the female mouse ovary and extragonadal tumorigenesis
}

\author{
Anne Bachelot, ${ }^{1,2}$ Nadège Carré,,${ }^{3,4}$ Olivier Mialon, ${ }^{3,4}$ Melody Matelot, ${ }^{3,4}$ Nathalie Servel, ${ }^{5}$ \\ Philippe Monget, ${ }^{6}$ Petteri Ahtiainen, ${ }^{7}$ Ilpo Huhtaniemi, ${ }^{7,8}$ and Nadine Binart ${ }^{3,4}$ \\ ${ }^{1}$ AP-HP, Endocrinology and Reproductive Medicine, Pitié-Salpêtrière Hospital, Paris, France; ${ }^{2}$ Université Pierre et Marie \\ Curie, Site Pitié, Paris, France; ${ }^{3}$ Université Paris-Sud, Faculté de Médecine Paris-Sud, UMR-S693, Paris-Sud, France; \\ ${ }^{4}$ INSERM U693, 94276 Kremlin-Bicêtre, France; ${ }^{5}$ INSERM U845, Paris, France; ${ }^{6}$ INRA, UMR85, Physiologie de la \\ Reproduction et des Comportements, Nouzilly, France; ${ }^{7}$ Department of Physiology, University of Turku, Turku, Finland; \\ and ${ }^{8}$ Institute of Reproductive and Developmental Biology, Imperial College London, London, United Kingdom
}

Submitted 1 May 2013; accepted in final form 4 August 2013

Bachelot A, Carré N, Mialon O, Matelot M, Servel N, Monget P, Ahtiainen P, Huhtaniemi I, Binart N. The permissive role of prolactin as a regulator of luteinizing hormone action in the female mouse ovary and extragonadal tumorigenesis. Am J Physiol Endocrinol Metab 305: E845-E852, 2013. First published August 6, 2013; doi:10.1152/ajpendo.00243.2013.- Transgenic female mice overexpressing the hCG $\beta$ subunit $\left(\mathrm{hCG}^{+}\right)$and producing elevated levels of luteinizing hormone $(\mathrm{LH}) / \mathrm{hCG}$ bioactivity present as young adults with enhanced ovarian steroidogenesis, precocious puberty, and infertility. They subsequently develop pituitary prolactinomas, high circulating prolactin (PRL) levels, and marked mammary gland lobuloalveolar development followed by adenocarcinomas. None of these phenotypes appear in gonadectomized mice, indicating that the hCGinduced aberrations of ovarian function are responsible for the extragonadal phenotypes. PRL receptor-deficient $\left(\mathrm{PRLR}^{-1-}\right)$ female mice are sterile, despite ovulating, due to a failure of embryo implantation, as a consequence of decreased ovarian LH receptor (Lhcgr) expression and inadequate corpus luteum formation and progesterone production. To study further the presumed permissive role of PRL in the maintenance of gonadal responsiveness to LH/hCG stimulation, we crossed the $\mathrm{hCG}^{+}$and $\mathrm{PRLR}^{-1-}$ mice. The double-mutant $\mathrm{hCG}^{+} / \mathrm{PRLR}^{-1-}$ females remained sterile with an ovarian phenotype similar to $\mathrm{PRLR}^{-1-}$ mice, indicating that $\mathrm{LH}$ action, Lhcgr expression, and consequent luteinization are not possible without simultaneous PRL signaling. The high frequency of pituitary prolactinomas in PRLR ${ }^{-1-}$ mice was not affected by transgenic hCG $\beta$ expression. In contrast, none of the $\mathrm{hCG} \beta^{+} / \mathrm{PRLR}^{-1-}$ females showed either mammary gland lobuloalveolar development or tumors, and the increased mammary gland $W n t-5 b$ expression, possibly responsible for the tumorigenesis in $\mathrm{hCG}^{+}$mice, was absent in double-mutant mice. Hence, high $\mathrm{LH} / \mathrm{hCG}$ stimulation is unable to compensate for missing PRL signaling in the maintenance of luteal function. PRL thus appears to be a major permissive regulator of $\mathrm{LH}$ action in the ovary and of its secondary extragonadal effects.

transgenic mice; mammary gland tumor; pituitary adenoma

TRANSGENIC (TG) mouse models have confirmed the key role of gonadotropins in normal reproductive function and as oncogenic factors in gonadal and extragonadal tumorigenesis (1, 21). To assess the consequences of prolonged exposure to elevated levels of luteinizing hormone ( $\mathrm{LH}$ )/choriongonadotropin (hCG) bioactivity, TG mice expressing the hCG $\beta$ subunit under the ubiquitin $\mathrm{C}$ promoter $\left(\mathrm{hCG}^{+}\right.$mice) have been developed (38). Female TG mice present initially with preco-

Address for reprint requests and other correspondence: N. Binart, INSERM U693, Le Kremlin-Bicêtre, France (e-mail: nadine.binart@inserm.fr). cious puberty, infertility, enhanced ovarian steroidogenesis, and elevated prolactin (PRL) levels. Several extragonadal phenotypes develop in the mice upon aging, including pituitary hyperplasia at the age of $2 \mathrm{mo}$, followed by gradual growth of pituitaries to macroprolactinomas at the age of 6 mo (2). In addition, marked mammary gland lobuloalveolar development, followed by adenocarcinomas, is observed at the age of 9-12 mo (38). Although Lhcgr expression has been detected in pituitary, adrenal, and breast tissues (3), it is apparent in this model that all extragonadal phenotypes are induced through hCG-stimulated ovarian endocrine activity because they all failed to occur if the mice were gonadectomized before puberty (38). The endocrine aberration of the $\mathrm{hCG}^{+}$mice with persistently elevated levels of PRL and progesterone, and transient peripubertally elevated estradiol, was most probably crucial for the mammary gland tumorigenesis, although direct extragonadal hCG effects cannot be excluded (20). A tumor promoter role for LH has also been proposed on the basis of other TG mouse models, including inhibin-deficient mice (26) and those expressing the Simian virus 40 T-antigen under inhibin $\alpha$-subunit promoter $(23,36)$. Transdifferentiation is observed in the mammary tumors of the $\mathrm{hCG}^{+}$mice, accompanied by abnormal expression of the $W n t-5 b$ and $-7 b$ genes in the tumorous and nontumorous mammary glands (24). Importantly, hCG was found to upregulate these Wnt ligands in the mouse mammary gland, independent of the changes in ovarian steroidogenesis (24). Thus, the $\mathrm{hCG}^{+}$mice represent a novel model that links enhanced hCG action to dysregulated Wnt signaling in the mammary gland, resulting in $\beta$-catenin-stabilizing mammary tumorigenesis (24).

Prolactin receptor-deficient $\left(\mathrm{PRLR}^{-/-}\right.$) female mice are sterile due to the failure of embryo implantation, which is, for a large part, due to the failure of corpus luteum (CL) maintenance, the consequence of decreased Lhcgr expression in the CL, and a consequent loss of the enzymatic cascades necessary to supply adequate levels of progesterone $(4,9,29)$. We have previously shown that Lhcgr upregulation is possible without concomitant PRL action because hCG treatment of PRLR ${ }^{-/-}$ mice at day 0.5 after ovulation for 2 days induced clear de novo expression of Lhcgr mRNA in the corpora lutea compared with those of wild-type (WT) ovaries, and that the LHR in hCGtreated PRLR ${ }^{-1-}$ animals was functional (5). The expression of Lhcgr was accompanied by increased expression of the steroidogenic enzymes involved in progesterone synthesis. Despite these positive effects, hCG-treated $\mathrm{PRLR}^{-1-}$ mice were unable to implant due to high early expression of $20 \alpha$ - 
hydroxysteroid dehydrogenase (20 $\alpha$-HSD), a PRL repressed luteal enzyme that catabolizes and inactivates progesterone.

To dissect out further the specific contribution of the different hormones, i.e., $\mathrm{LH} / \mathrm{hCG}$, PRL, and steroids, in the gonadal and extragonadal phenotypes displayed by the $\mathrm{hCG}^{+}$and $\mathrm{PLR}^{-1-}$ mice, we intercrossed in the present study the TG hCG $\beta^{+}$and PRLR knockout mice.

\section{MATERIALS AND METHODS}

Animals. TG female mice of the FVB/N strain expressing heterozygously the $h C G \beta$-subunit cDNA, driven by the human ubiquitin $\mathrm{C}$ promoter, and their genotyping and housing have been described before (38). Non-TG littermates were used as controls. WT and PRLR $^{+/-}$female mice $(129 / \mathrm{SvJ})$ were generated as previously described (31) and then backcrossed by successive 12 breedings to a pure genetic $\mathrm{FVB} / \mathrm{N}$ background. $\mathrm{hCG} \beta^{+}$male and $\mathrm{PRL}^{+/-}$mice were intercrossed to obtain $\mathrm{hCG}^{+}$and $\mathrm{hCG} \beta^{+} / \mathrm{PRL}^{-\prime-}$ female mice. PCR analysis of tail DNA was used to determine the genotypes of the offspring as described previously $(31,38)$. Animals were housed in a $12: 12$-h day-night cycle at $22^{\circ} \mathrm{C}$ and relative humidity of $50 \%$ with food and water ad libitum. Mice were bred according to the Guide for the Care and Use of Laboratory Animals published by the United States National Institute of Health (NIH Publication No. 85-23, revised 1996). The animal facility was granted approval (No. C94-043-12), given by the French Administration. All procedures were approved by the local ethic committee CAPSud (No. 2012-021).

Fertility studies. For testing the fertility, $\mathrm{hCG}^{+}$and $\mathrm{hCG}^{+} /$ $\mathrm{PRLR}^{-1-}$ female mice were bred with WT males for up to $6 \mathrm{mo}$, and vaginal plugs were checked. The duration of estrous cycles was determined in six $\mathrm{hCG}^{+}$and $\mathrm{hCG}^{+} / \mathrm{PRLR}^{-1-}$ female mice and WT mice by daily analysis of the vaginal smears for a period of $4 \mathrm{wk}$. For implantation study, the morning a vaginal plug was found was designated day 0.5 of pregnancy. On day 5.5, the mice were killed, and the number of implantation sites was recorded by monitoring the localized uterine vascular permeability at the sites of blastocysts after intravenous injection of Chicago blue dye solution in saline (Sigma, St. Louis, MO).

Histological analysis. Tissues (ovaries, pituitaries, and adrenal glands) were fixed overnight in $4 \%$ paraformaldehyde, dehydrated, and embedded in paraffin, and 5- $\mu$ m-thick sections were prepared. For histological studies, sections were stained with hematoxylin and eosin.

Mammary gland whole mounts. The fourth inguinal mammary glands were dissected out, spread on glass slides, and fixed overnight in a 1:3 mixture of glacial acetic acid-100\% ethanol at room temperature. The tissues were washed in $70 \%$ ethanol, rinsed in water, and stained overnight in $0.2 \%$ carmine (Sigma) at room temperature. The stained tissues were dehydrated through graded series of ethanol, cleared in toluene, and mounted.

Binding assays on histological sections. Ovaries were collected and coated with cryoprotectant embedding medium (Tissue-Tek; Miles, Elkhart, IN), frozen in cold isopentane, and then stored at $-20^{\circ} \mathrm{C}$. The binding of ${ }^{125}$ I-labeled hCG to ovarian frozen sections was studied by an autoradiographic method, as described previously (17). Briefly, ovaries were serially sectioned at a thickness of $5 \mu \mathrm{m}$ with a cryostat. After fixation for $10 \mathrm{~min}$ at $4{ }^{\circ} \mathrm{C}$ in picric acid-formaldehyde, sections were stored at $-20^{\circ} \mathrm{C}$ and then circled with Depex (Gurr; BDH, Poole, UK). hCG was iodinated by the Iodogen method (Sigma, St. Quentin, France) and purified by Sephadex G-50 chromatography. Sections were incubated in a drop of PBS (0.1\% BSA, pH 7.4) containing ${ }^{125} \mathrm{I}$-labeled hCG $\left(4 \times 10^{5} \mathrm{cpm} / 50 \mu \mathrm{l}\right)$. To determine nonspecific binding, for the tested ligand an adjacent serial section of ovary was incubated with an excess of unlabeled ligand $(500 \mathrm{ng} / 50 \mu \mathrm{l}$ hCG). At the end of the incubation period, the sections were washed two times in PBS, postfixed in $3 \%$ glutaraldehyde-PBS, washed in
PBS, air-dried, and stained with Feulgen. For autoradiography, they were then dipped in Kodak NTB2 emulsion diluted 1:1 with distilled water, air-dried, exposed for $2 \mathrm{wk}$ at $4{ }^{\circ} \mathrm{C}$, and then developed and fixed by classical procedures.

$R N A$ isolation and quantitative RT-PCR. The fourth mammary gland or mammary gland tumor was excised and snap-frozen in liquid nitrogen. Total RNA was extracted from the tissues using Trizol reagent (Invitrogen). Quantitative real-time PCR was performed as described previously (44). After DNase I treatment, RNA was reverse-transcribed and used for quantitative RT-PCR using the Power SYBR Green PCR Master Mix (Applied Biosystems). All primer pairs used were intron spanning: Wnt $5 \mathrm{~b}$ sense, TGGAGACAACGTGGAGTACG; Wnt 5b antisense, GGCGACATCAGCCATCTTAT; product size $166 \mathrm{bp}$; T annealing $60^{\circ} \mathrm{C}$. The presence of a single, correct-sized PCR product was confirmed by running the samples on $2 \%$ agarose gels. Final primer concentrations were $300 \mathrm{nM}$. Reaction parameters were carried out on a StepOne Real-Time PCR System (Applied Biosystems). Relative expression within a given sample was calculated as a ratio (amol of specific gene/fmol of 18S).

Statistical analysis. Descriptive statistics were performed for each variable, and parameters were compared using the MannWhitney test. Proportions for the two groups were compared using the $\chi^{2}$-test. All values are expressed as means \pm SE of combined data from the replicate experiments. Tumor-free survival curves were carried out by the Kaplan-Meier method and compared with the log-rank test; all data were expressed as means $\pm 95 \%$ confidence intervals. Analyses were processed with GraphPad Prism 5 (GraphPad Software, La Jolla, CA). Values of $P<0.05$ were considered statistically significant.

\section{RESULTS}

Fertility, estrous cycles, and ovarian histology. hCG ${ }^{+}$ females presented, at 3 mo of age, with irregular estrous cycles, with only one out of four mice exhibiting estrus during the 4 -wk period of observation and the remaining mice showing a continuous diestrus pattern. Next, at 6 mo of age, all hCG $\beta^{+}$females $(n=10)$ presented with a diestrustype pattern, and no pregnancies were observed during the 6-mo breeding period with WT males. hCG ${ }^{+} / \mathrm{PRLR}^{-/-}$ mice exhibited regular estrous cycles [duration: $6.8 \pm 1.5$ days $(n=4)$ vs. $6.7 \pm 0.5$ days in WT mice $(n=8), P=$ not significant] at 3-10 mo of age. However, despite the regular estrous cycles, $\mathrm{hCG}^{+} / \mathrm{PRLR}^{-1-}$ females could not achieve pregnancy following breeding with WT males (observation for up to $6 \mathrm{mo}$ ), despite the presence of periodic vaginal plugs. We examined the number of implantation sites in four hCG $\beta^{+} / \mathrm{PRLR}^{-/-}$females on day $5.5 \mathrm{using}$ the blue dye method. No implantation sites were observed, in compliance with the phenotype already described in the $\mathrm{PRLR}^{-1-}$ model mice (9). At diestrous, histological analysis of the ovaries in all genotypes at 3 and 6 mo of age is shown in Fig. 1. The $\mathrm{hCG}^{+}$mice presented with progressive luteinization of their ovaries, with presence of few follicles at various stages of maturation and multiple large luteomas. The $\mathrm{hCG}^{+} / \mathrm{PRLR}^{-/-}$ovaries showed all classes of follicles but absence of corpora lutea or luteomas, a phenotype similar to PRLR ${ }^{-1-}$ females already described (9).

To examine whether the LHR protein was synthesized and able to bind the ligand hormone, we performed ${ }^{125}$ I-labeled hCG binding analysis on ovarian sections (Fig. 2). The results showed high levels of hCG binding activity in the whole hCG $\beta^{+}$ovaries (apparently in luteoma tissue) compared with WT mice where LH-binding activity was mostly fond in 

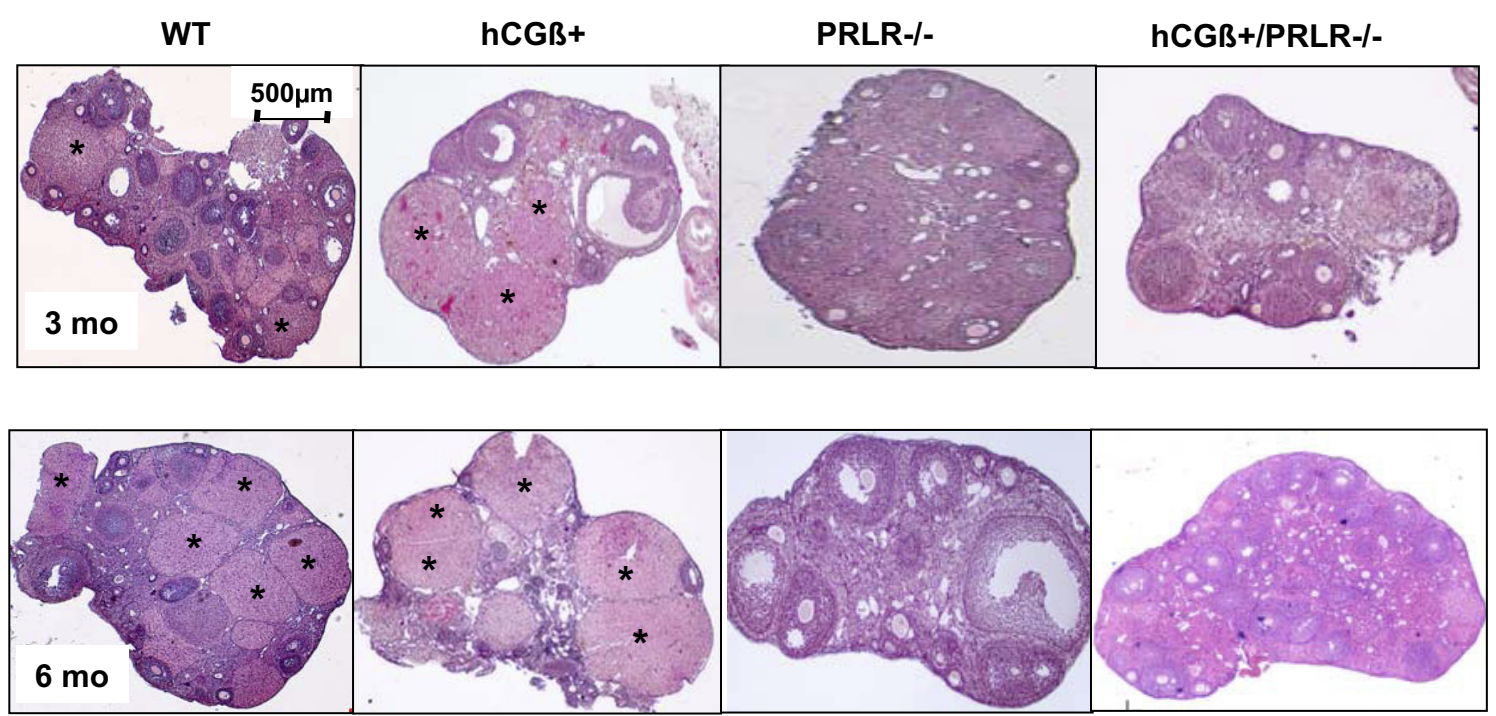

Fig. 1. Histological analysis of ovaries from wild-type (WT) mice, transgenic mice expressing the choriongonadotropin (hCG) $\beta$-subunit under the ubiquitin C promoter $\left(\mathrm{hCG} \beta^{+}\right)$, prolactin receptor-deficient $\left(\mathrm{PRLR}^{-1-}\right)$ mice, and hCG $\beta^{+} / \mathrm{PRLR}^{-1-}$ mice. Representative views of ovarian sections stained with hematoxylin-eosin are from 3- and 6-mo-old mice. All ovaries contain all developmental stages of follicles, but luteal tissue (asterisks) is found only in hCG $\beta^{+}$ and WT ovaries. Scale bar $=500 \mu \mathrm{m}$. Representative view of ovary $(n=5 /$ group $)$.

corpora lutea. None of the $\mathrm{hCG} \beta^{+} / \mathrm{PRLR}^{-1-}$ and $\mathrm{PRLR}^{-1-}$ mice showed corpora lutea or luteomas with clear LHR expression. High TG $\mathrm{LH} / \mathrm{hCG}$ bioactivity was therefore not sufficient to reverse the female PRLR ${ }^{-1-}$ reproductive phenotype, indicating that LH action, Lhcgr expression, and consequent luteinization did not occur in the absence of PRL signaling.

Mammary gland development. Whole mount analysis of the mature mammary glands from virgin mice of all genotypes, performed at the ages of 3,6 , and 9 mo, is shown in Fig. 3 . There was a substantial and dramatic lobuloalveolar develop-
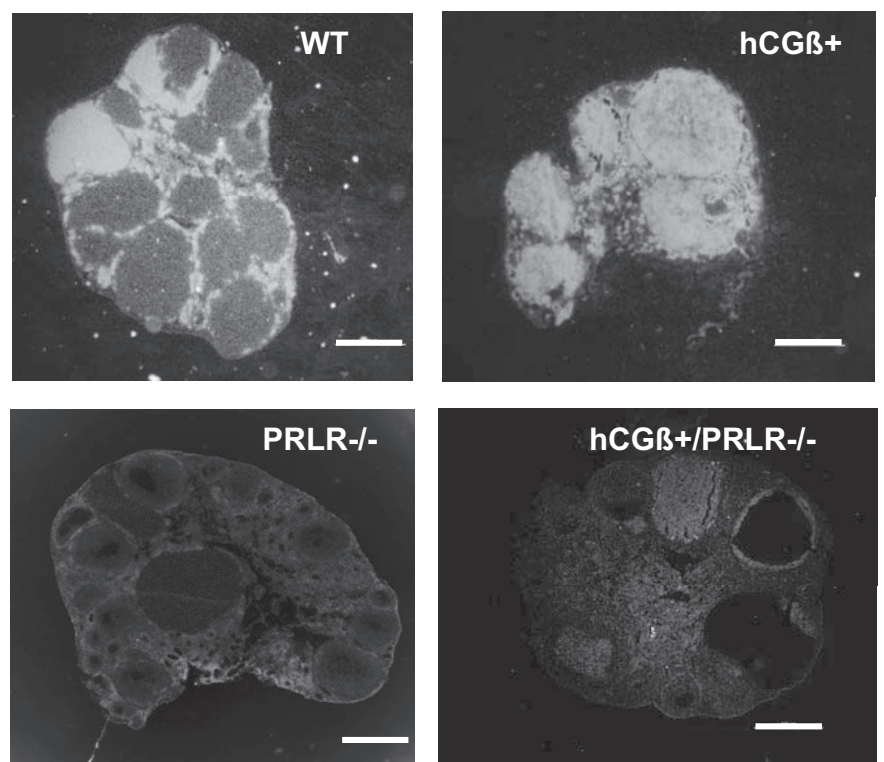

Fig. 2. Localization of binding sites for luteinizing hormone (LH)/hCG in ovaries from WT, $\mathrm{hCG}^{+}, \mathrm{PRLR}^{-1-}$, and $\mathrm{hCG} \beta^{+} / \mathrm{PRL}^{-1-}$ mice. Binding of ${ }^{125}$ I-labeled hCG to ovarian frozen sections was studied by an autoradiographic method. Specific and intense labeling was found in $\mathrm{WT}$ and $\mathrm{hCG}^{+}$mouse ovaries, contrasting with absent/very weak labeling in $\mathrm{PRL}^{-1-}$ and $\mathrm{hCG}^{+}$/ $\operatorname{PRLR}^{-1-}$ ovaries ( $n=3$ /genotype). Scale bar $=500 \mu \mathrm{m}$. ment from the age of 6 mo in the hCG $\beta^{+}$compared with WT mice, reminiscent of the phenotype of the pregnant mammary gland. In contrast, none was observed in the $\mathrm{hCG}^{+}$/ $\mathrm{PRLR}^{-1-}$ and $\mathrm{PRLR}^{-1-}$ female lobuloalveolar development; moreover, the side branching appears very poor compared with those of the WT mice. $\mathrm{hCG}^{+}$mice developed aggressive mammary gland tumors after the age of 9 mo, with rapidly growing tumor mass and necrosis found in the center of the tumors (Fig. 4A). Based on histological criteria, the tumors were mammary infiltrating adenocarcinomas (Fig. $4 B$ ) or papillary pilar carcinomas (Fig. $4 C$ ) as the main subtypes. These tumors had a high prevalence compared with WT mice $(P<0.001$, Fig. $5 A)$, and they were never found in $\mathrm{PRLR}^{-1-}$ or in $\mathrm{hCG} \beta^{+} / \mathrm{PRLR}^{-1-}$ mice during the observation period (Fig. 5A).

Wnt signaling in the mammary gland is dysregulated in the $\mathrm{hCG}^{+}$mice, resulting in $\beta$-catenin-stabilizing mammary tumorigenesis (23). Results of the qPCR analysis of mammary glands and mammary tumors of the $\mathrm{hCG}^{+}, \mathrm{hCG} \beta^{+}$/ $\mathrm{PRLR}^{-1-}$, and WT females are shown in Fig. 5B. Increased expression of Wnt-5b was present even in the absence of macroscopic tumors in the $\mathrm{hCG} \beta^{+}$mammary glands compared with control and hCG $\beta^{+} / \mathrm{PRLR}^{-1-}$ and $\mathrm{PRLR}^{-1-}$ mice (Fig. $5 B$ ). Similar results were observed for $W n t-7 b$ expression (data not shown).

Pituitary adenomas. The pituitary glands of $\mathrm{PRLR}^{-1-}$ mice contained massive, multifocal tumors, all monohormonal lactotroph adenomas, as well as the pituitary of $\mathrm{hCG}^{+}$mice (3). Next, we studied the prevalence of pituitary adenomas in all genotypes. $\mathrm{hCG}^{+} / \mathrm{PRLR}^{-1-}$ and $\mathrm{PRLR}^{-1-}$ females had slightly enlarged pituitary glands at 6 mo of age and massively enlarged at 14 mo, leading to death of the animals (Fig. 6). $\mathrm{hCG}^{+} / \mathrm{PRLR}^{-1-}$ and $\mathrm{PRLR}^{-1-}$ mice exhibited tumors more frequently than did $\mathrm{hCG} \beta^{+}$or WT mice.

Adrenal glands. Chronically elevated serum LH, augmented by enhanced PRL production, has been shown to induce 


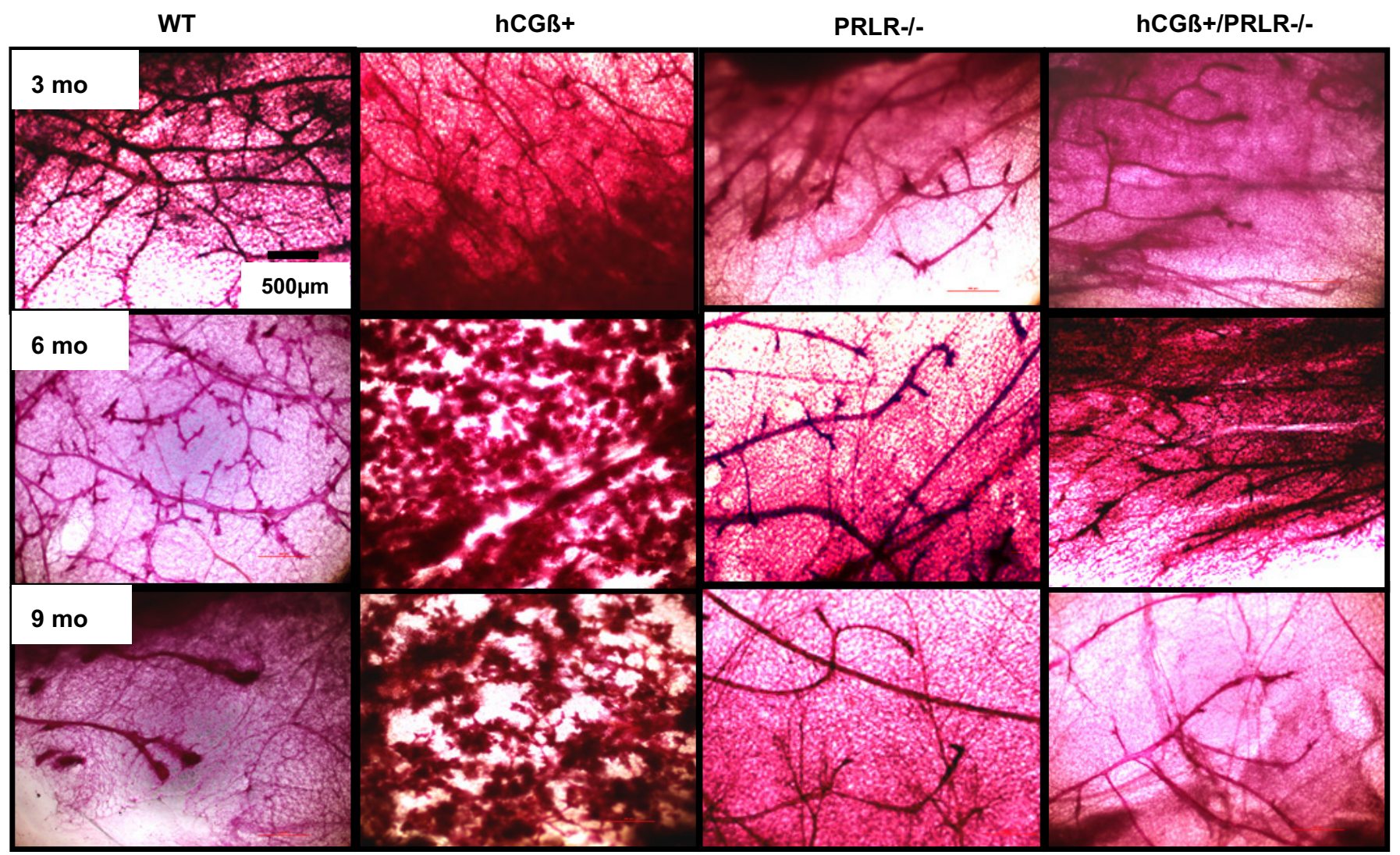

Fig. 3. Whole mount analysis of mammary gland from $\mathrm{WT}, \mathrm{hCG} \beta^{+}, \mathrm{PRLR}^{-1-}$, and $\mathrm{hCG} \beta^{+} / \mathrm{PRLR}^{-1-}$ virgin female mice performed at the age of 3,6 , and 9 mo. A representative mammary gland is shown $\left(n=5 /\right.$ genotype). There was substantial lobuloalveolar development in 6-mo-old hCG $\beta^{+}$mice, compared with WT mice, reminiscent of the phenotype of the pregnant mammary gland. None of the PRLR ${ }^{-1-}$ and $h C G \beta^{+} / \mathrm{PRLR}^{-1-}$ females showed lobuloalveolar development. Scale bar $=500 \mu \mathrm{m}$.

functional Lhcgr expression in the adrenal cortex of specific strains of mice (8). Histological analysis of the adrenal glands, performed at the ages of 3, 6, and 9-12 mo, showed no differences between any of the genotypes, with an absence of hyperplasia or tumor development (data not shown). By LH- binding analysis, we were not able to evidence LHR in adrenal gland, whatever the genotype or the age of the mice (result not shown). We confirm here the earlier finding (8) that the FVB/N mouse strain is resistant to postgonadectomy/high gonadotropin-induced adrenal tumorigenesis.
Fig. 4. A: representative macroscopic examination of a mammary tumor in 12 -mo-old $\mathrm{hCG} \beta^{+}$female mouse. $B$ and $C$ : hematoxylin and eosin staining of sections of two mammary gland tumors (infiltrating adenocarcinoma and differentiated carcinoma) in $\mathrm{hCG} \beta^{+}$female mouse at 12 mo of age.

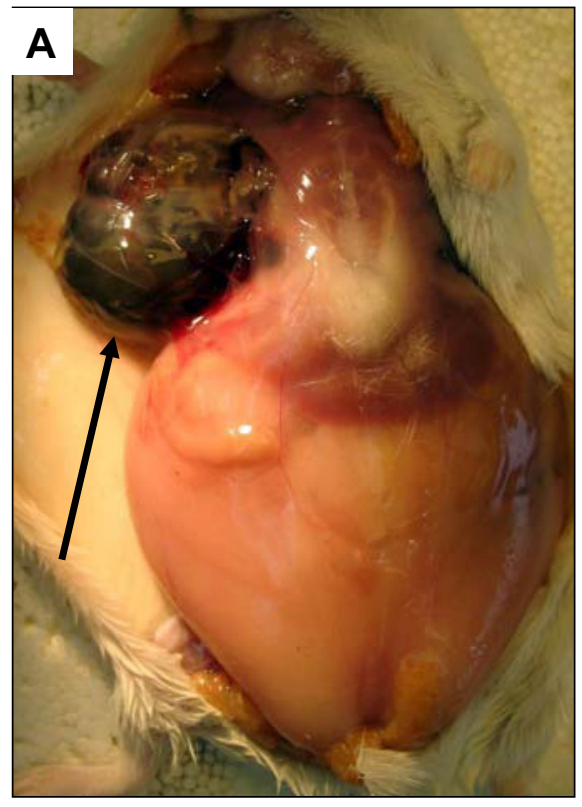

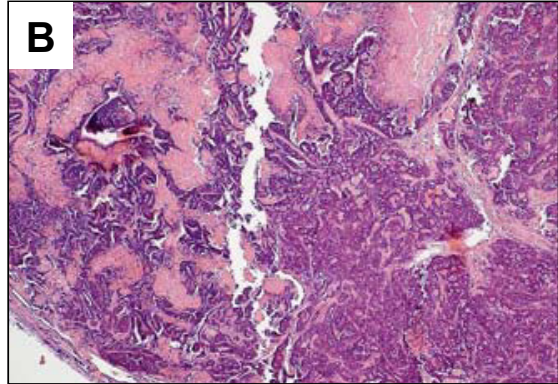

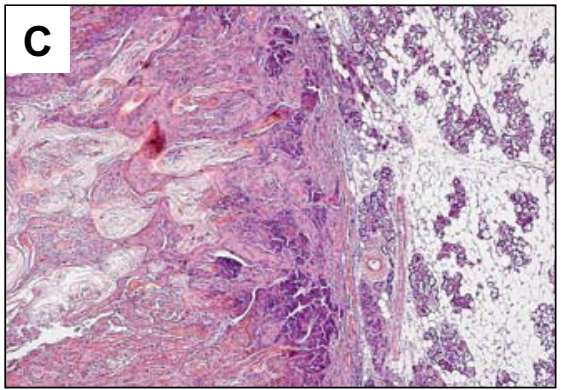


A

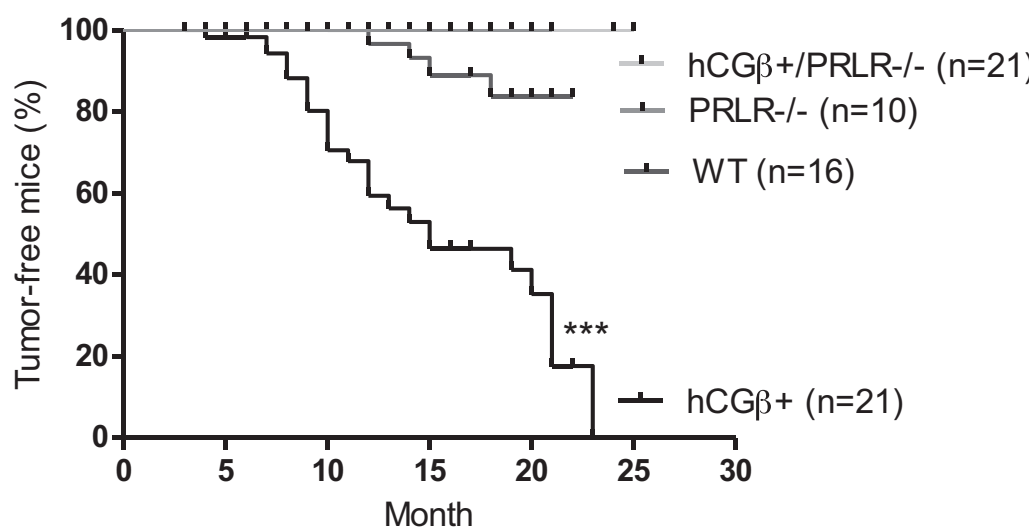

B

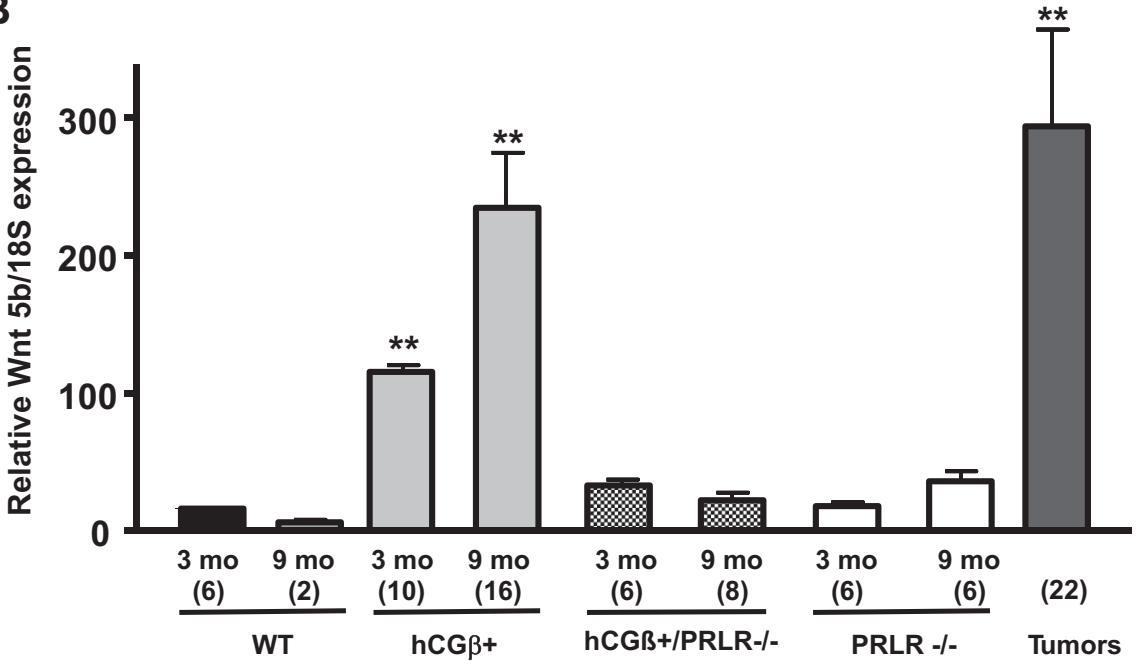

Fig. 5. A: incidence of mammary tumors in female WT, $\mathrm{hCG}^{+}, \mathrm{PRLR}^{-/-}$, and $\mathrm{hCG}^{+} / \mathrm{PRLR}^{-1-}$ mice. The Kaplan-Meier plot shows a high prevalence of mammary tumors in $\mathrm{hCG}^{+}$compared with WT mice until $25 \mathrm{mo}$; these tumors were never observed in $\mathrm{PRLR}^{-1-}$ and $\mathrm{hCG}+/ \mathrm{PRLR}^{-1-}$ mice during the observation period. Log rank test $* * * P<0.001$ vs. other groups. $B$ : quantitative RT-PCR of $W n t-5 b$ expression in $\mathrm{WT}, \mathrm{hCG}^{+}, \mathrm{hCG} \beta^{+} / \mathrm{PRLR}^{-1-}$, and PRLR $^{-1-}$ mammary glands at 3 and 9 mo of age as well as in tumors. Increased expression of Wnt-5b was present even in the absence of macroscopic tumors in the $\mathrm{hCG}^{+}$mammary glands compared with control and $\mathrm{hCG}^{+} / \mathrm{PRLR}^{-1-}$ and $\mathrm{PRLR}^{-1-}$ mice. Nos. of animals are shown in parentheses. **Statistically significant difference compared with WT mice $(P<0.01)$.

\section{DISCUSSION}

We have previously shown that hyperprolactinemia is essential for the phenotypic defects in hCG-overexpressing mice (38). Hyperprolactinemia is induced in these mice by combined action of a peripubertal peak in ovarian estradiol production and persistent high progesterone levels produced by the ovarian luteomas. The reproductive phenotype of the mice includes completely disturbed cyclicity and infertility. The crucial role of hyperprolactinemia in this phenotype was demonstrated recently by short-term cabergoline treatment, which prevented the reproductive dysfunction of these mice (35). Conversely, targeted disruption of the Prlr gene in female mice results in infertility by completely disturbing both the mainte- nance of CL, decreasing the expression of Lhcgr, and by increasing the expression of $20 \alpha-h s d$, leading to progesterone insufficiency and blockage of embryo implantation and mammary gland development $(5,19)$. We observed in this study that chronic overexpression of hCG in PRLR ${ }^{-1-}$ females was not able to rescue their fertility, supporting the permissive role of PRL in the maintenance of reproductive function. We showed also that the absence of PRL signaling protected the $\mathrm{hCG}^{+}$/ $\mathrm{PRLR}^{-1-}$ mice from mammary gland tumorigenesis that occurs in $\mathrm{hCG} \beta^{+}$mice in the presence of functional PRLR and high ovarian steroid hormone production.

PRL regulates the expression of a number of genes important for CL function and which may secondarily maintain

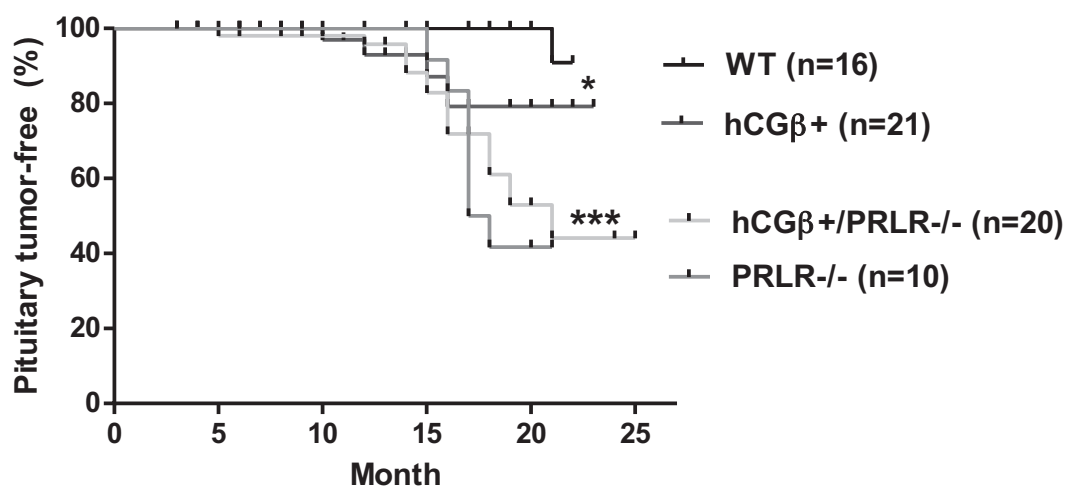

Fig. 6. Incidence of pituitary adenomas in $\mathrm{WT}, \mathrm{hCG} \beta^{+}$, $\mathrm{PRLR}^{-1-}$, and $\mathrm{hCG}^{+} / \mathrm{PRLR}^{-1-}$ female mice. The pituitary glands of $\mathrm{PRLR}^{-1-}$ and $\mathrm{hCG}^{+} / \mathrm{PRLR}^{-1-}$ mice were enlarged after 3 mo of age compared with WT mice, and persistent growth occurred thereafter, leading to death of animals. $* P<0.05$ and $* * * P<0.001$ vs. WT. 
progesterone secretion and thereby gestation (42). It has been shown early on that PRL is essential for Lhcgr expression in rodent CL $(16,18,33,41)$, and the generation of the Prlrdeficient mice further substantiated these functions (19). LH is an important stimulus of CL function in a number of species, including humans and rodents (42). Earlier studies have established the timing and the role of PRL and LH in the maintenance of luteal function from day 7 through day 11 of pregnancy $(28,37)$. Here we showed that no pregnancies were observed in $\mathrm{hCG}^{+} / \mathrm{PRLR}^{-1-}$ females, despite presenting with regular cycles and ovulations, as evidenced by regular plug observation. Instead, the mice had implantation failure, a reproductive phenotype similar to $\mathrm{PRLR}^{-1-}$ mice already described (9). Therefore, overexpression of hCG in the absence of PRL signaling was unable to restore luteinization, strengthening the evidence of PRL dependence of the regulation of Lhcgr expression, as shown by hCG-binding analysis. Of note, we have previously reported that acute $\mathrm{LH} / \mathrm{hCG}$ stimulation of $\mathrm{PRLR}^{-1-}$ females can induce, if administered early during CL formation, the expression and binding activity of LHR in the $\mathrm{CL}$ in the total absence of PRL signaling (5). We also showed that $\mathrm{LH} / \mathrm{hCG}$ stimulated the expression of steroidogenic enzymes in the absence of PRL signaling. However, despite these positive effects, the level of progesterone secretion remained too low to allow blastocyst implantation. These results suggested that, although the activation of ovarian steroidogenesis is possible without concomitant PRL action, the rapid catabolism of progesterone persisted due to the persistent upregulation of $20 \alpha$-HSD in the absence of PRL effect.

One of the remarkable features of the $\mathrm{hCG} \beta^{+}$mouse model is the development of the mammary gland phenotype, culminating in formation of malignant mammary tumors in older age $(24,38)$. We showed in this study that the lack of PRL signaling is able to protect against mammary gland tumorigenesis. Several hormones, including estrogens, progesterone, PRL, glucocorticoids, and a number of growth factors, contribute to the normal development and carcinogenesis of the mammary gland $(11,14,34)$. Indeed, TG and knockout mouse models have proven useful for elucidating their contribution to the regulation of mammary gland growth and differentiation $(12,13,45,46)$. Ovarian steroids and PRL are the likely inducers of mammary tumorigenesis in the $\mathrm{hCG}^{+}$mice because it is completely prevented if the mice are gonadectomized before puberty (38). We have previously shown that PRLR is required for pregnancy-induced lobuloalveolar development. PRLR ${ }^{-1-}$ mice exhibit a phenotype similar to that observed in the progesterone receptor-deficient mice. This was supported by the evidence that progesterone can regulate PRLR expression (30). Even if the side-branching defect observed in PRLR ${ }^{-1-}$ mammary glands can be rescued with progesterone treatment, the lobuloalveolar development still did not occur (9).

Our results demonstrate that the precocious abnormal lobuloalveolar development of the mammary gland in $\mathrm{hCG}^{+}$ females is either dependent on ovarian endocrine hyperfunction or on PRL signaling. Accordingly, cross talk between the steroid hormones and the PRL pathway is able to synergize on mammary epithelium (14). The final way to dissect out the specific contribution of the different hormones would be to cross the hCG $\beta^{+}$mice individually with mice deficient of the estrogen and progesterone receptors. Although Lhcgr is ex- pressed in mouse mammary gland, its direct stimulation by the high circulating hCG levels is unlikely because we have previously shown that Lhcgr knockout mice carrying orthotopic transplants of WT ovary can become pregnant, and their mammary glands undergo normal pregnancy-associated lobuloalveolar maturation to enable lactation (32).

In humans, the role of PRL in the development of breast cancer still remains controversial. Some authors reported associations between PRL or hPRLR single-nucleotide polymorphisms and the risk of breast cancer $(15,25,43)$, but no functional analysis has been undertaken to provide causality and mechanistic insight into these associations. This question prompts further studies on the involvement of the hPRLR in breast disease pathogenesis. Wnt signaling in the mammary gland was dysregulated in the $\mathrm{hCG} \beta^{+}$mice, as previously described (24), resulting in $\beta$-catenin-stabilizing mammary tumorigenesis. This response was not observed in the absence of PRL signaling, suggesting that disturbed Wnt signaling is dependent of PRL action, either directly or via LH/hCG stimulation of ovarian steroidogenesis. Hence, this mouse model provides novel information about hCG action and hormonally induced tumorigenesis of the breast.

We have previously demonstrated an amplifying effect of progesterone on the growth of estrogen-induced pituitary tumors in the $\mathrm{hCG}^{+}$mice $(1,2)$. Also, the $\mathrm{PRLR}^{-1-}$ mice exhibit pituitary hyperplasia and adenoma formation (40). In these mice, two factors contribute to the release of the lactotroph from its usual secretory and proliferative controls: a decrease in the normally inhibitory dopaminergic control and a second, direct effect at the level of the pituitary that is most consistent with an antiproliferative action of PRL on lactotrophs (40). Knowing that PRL is a stimulator of progesterone secretion, we observed pituitary adenomas in PRLR ${ }^{-1-}$ and $\mathrm{hCG} \beta^{+} / \mathrm{PRLR}^{-1-}$ mice. However, no additive effect was shown in the $\mathrm{hCG}^{+}$mice, suggesting that the deletion of PRLR is a stronger stimulus of lactotroph growth than elevated progesterone level.

Finally, we assessed adrenal gland morphology, since chronically elevated serum LH, augmented by enhanced PRL production (22), has been shown to induce functional LHR expression in the adrenal cortex of certain strains of mice, and that chronically elevated $\mathrm{LH} / \mathrm{hCG}$ levels might stimulate growth and steroidogenesis of the adrenal cortex (7). Indeed, postgonadectomy tumorigenesis is thought to represent metaplasia of the subcapsular adrenocortical stem/progenitor cells between the zona glomerulosa and fasciculate that, under the influence of $\mathrm{LH}$, transform into cells resembling gonadal stroma $(6,8,27)$. Histological analysis of the adrenal glands showed no differences between genotypes, and absence of tumor development. This is in accordance with our previous work, which has demonstrated that adrenals of $\mathrm{FVB} / \mathrm{N}$ mice appear resistant to postgonadectomy alterations (8).

The fertility parameters and eventual tumor formation of male mice was not evaluated since PRLR ${ }^{-1-}$ and and $\mathrm{hCGb}^{+}$ males $(10,39)$ were both described as fertile, and that the exposure of male mice to chronically elevated levels of hCG was not sufficient to promote testicular tumor formation.

In conclusion, persistently high $\mathrm{LH} / \mathrm{hCG}$ stimulation is unable to compensate for missing PRL signaling in the maintenance of mouse luteal function, but the absence of PRLR expression prevents mammary gland tumorigenesis induced by 
hCG overexpression. PRL action thus appears to be a major permissive regulator of LH action directly in the ovary and, indirectly, through ovarian steroidogenesis, in the mammary gland. This work paves the way for future studies on the molecular pathways involved in hormone-dependent tumorigenesis of the mammary and pituitary glands.

\section{GRANTS}

A. Bachelot was supported by fellowships from La Fondation pour la Recherche Médicale.

\section{DISCLOSURES}

No conflicts of interest, financial or otherwise, are declared by the authors.

\section{AUTHOR CONTRIBUTIONS}

Author contributions: A.B., P.A., I.T.H., and N.B. conception and design of research; A.B., N.C., O.M., M.M., N.S., and P.M. performed experiments; A.B., I.T.H., and N.B. analyzed data; A.B., I.T.H., and N.B. interpreted results of experiments; A.B. and N.B. prepared figures; A.B. and N.B. drafted manuscript; I.T.H. and N.B. edited and revised manuscript.

\section{REFERENCES}

1. Ahtiainen P, Rulli S, Pakarainen T, Zhang FP, Poutanen M, Huhtaniemi I. Phenotypic characterisation of mice with exaggerated and missing LH/hCG action. Mol Cell Endocrinol 260-262: 255-263, 2007.

2. Ahtiainen P, Sharp V, Rulli SB, Rivero-Müller A, Mamaeva V, Röyttä M, Huhtaniemi I. Enhanced LH action in transgenic female mice expressing hCGbeta-subunit induces pituitary prolactinomas; the role of high progesterone levels. Endocr Relat Cancer 17: 611-621, 2010.

3. Ascoli M, Fanelli F, Segaloff DL. The lutropin/choriogonadotropin receptor, a 2002 perspective. Endocr Rev 23: 141-174, 2002.

4. Bachelot A, Binart N. Corpus luteum development: lessons from genetic models in mice. Curr Top Dev Biol 68: 49-84, 2005.

5. Bachelot A, Beaufaron J, Servel N, Kedzia C, Monget P, Kelly PA, Gibori G, Binart N. Prolactin independent rescue of mouse corpus luteum life span: identification of prolactin and luteinizing hormone target genes. Am J Physiol Endocrinol Metab 297: E676-E684, 2009.

6. Bernichtein S, Petretto E, Jamieson S, Goel A, Aitman TJ, Mangion JM, Huhtaniemi IT. Adrenal gland tumorigenesis after gonadectomy in mice is a complex genetic trait driven by epistatic loci. Endocrinology 149: 651-661, 2008.

7. Bernichtein S, Peltoketo H, Huhtaniemi I. Adrenal hyperplasia and tumours in mice in connection with aberrant pituitary-gonadal function. Mol Cell Endocrinol 300: 164-168, 2009.

8. Bielinska M, Parviainen H, Porter-Tinge SB, Kiiveri S, Genova E, Rahman N, Huhtaniemi IT, Muglia LJ, Heikinheimo M, Wilson DB. Mouse strain susceptibility to gonadectomy-induced adrenocortical tumor formation correlates with the expression of GATA-4 and luteinizing hormone receptor. Endocrinology 144: 4123-4133, 2003.

9. Binart N, Helloco C, Ormandy CJ, Barra J, Clément-Lacroix P, Baran N, Kelly PA. Rescue of preimplantatory egg development and embryo implantation in prolactin receptor-deficient mice after progesterone administration. Endocrinology 141: 2691-2697, 2000.

10. Binart N, Melaine N, Pineau C, Kercret H, Touzalin AM, ImbertBolloré P, Kelly PA, Jégou B. Male reproductive function is not affected in prolactin receptor-deficient mice. Endocrinology 144: 3779-82, 2003.

11. Binart N, Bachelot A, Bouilly J. Impact of prolactin receptor isoforms on reproduction. Trends Endocrinol Metab 21: 362-368, 2010.

12. Bocchinfuso WP, Lindzey JK, Hewitt SC, Clark JA, Myers PH, Cooper R, Korach KS. Induction of mammary gland development in estrogen receptor-alpha knockout mice. Endocrinology 141: 2982-2994, 2000.

13. Brisken C, Kaur S, Chavarria TE, Binart N, Sutherland RL, Weinberg RA, Kelly PA, Ormandy CJ. Prolactin controls mammary gland development via direct and indirect mechanisms. Dev Biol 210: 96-106, 1999.

14. Brisken C, O'Malley B. Hormone action in the mammary gland. Cold Spring Harb Perspect Biol 2: a003178, 2010.

15. Canbay E, Degerli N, Gulluoglu BM, Kaya H, Sen M, Bardakci F. Could prolactin receptor gene polymorphism play a role in pathogenesis of breast carcinoma? Curr Med Res Opin 20: 533-540, 2004.
16. Fan HY, Liu Z, Johnson PF, Richards JS. CCAAT/enhancer-binding proteins (C/EBP)-alpha and -beta are essential for ovulation, luteinization, and the expression of key target genes. Mol Endocrinol 25: 253-268, 2011.

17. Froment P, Seurin D, Hembert S, Levine JE, Pisselet C, Monniaux D, Binoux M, Monget P. Reproductive abnormalities in human IGF binding protein-1 transgenic female mice. Endocrinology 143: 1801-1808, 2002.

18. Gafvels M, Bjurulf E, Selstam G. Prolactin stimulates the expression of luteinizing hormone/chorionic gonadotropin receptor messenger ribonucleic acid in the rat corpus luteum and rescues early pregnancy from bromocriptine-induced abortion. Biol Reprod 47: 534-540, 1992.

19. Grosdemouge I, Bachelot A, Lucas A, Baran N, Kelly PA, Binart N. Effects of deletion of the prolactin receptor on ovarian gene expression. Reprod Biol Endocrinol 1: 1-12, 2003.

20. Huhtaniemi I, Rulli S, Ahtiainen P, Poutanen M. Multiple sites of tumorigenesis in transgenic mice overproducing hCG. Mol Cell Endocrinol 234: 117-126, 2005.

21. Huhtaniemi I. Are gonadotrophins tumorigenic-a critical review of clinical and experimental data. Mol Cell Endocrinol 329: 56-61, 2010.

22. Kananen K, Rilianawati Paukku T, Markkula M, Rainio EM, Huhtaniemi I. Suppression of gonadotropins inhibits gonadal tumorigenesis in mice transgenic for the mouse inhibin alpha-subunit promoter/simian virus 40 T-antigen fusion gene. Endocrinology 138: 3521-3531, 1997.

23. Kero J, Poutanen M, Zhang FP, Rahman N, McNicol AM, Nilson JH, Keri RA, Huhtaniemi IT. Elevated luteinizing hormone induces expression of its receptor and promotes steroidogenesis in the adrenal cortex. $J$ Clin Invest 105: 633-641, 2000.

24. Kuorelahti A, Rulli S, Huhtaniemi I, Poutanen M. Human chorionic gonadotropin (hCG) up-regulates wnt5b and wnt7b in the mammary gland, and hCGbeta transgenic female mice present with mammary Gland tumors exhibiting characteristics of the Wnt/beta-catenin pathway activation. Endocrinology 148: 3694-3703, 2007.

25. Lee SA, Haiman CA, Burtt NP, Pooler LC, Cheng I, Kolonel LN, Pike MC, Altshuler D, Hirschhorn JN, Henderson BE, Stram DO. A comprehensive analysis of common genetic variation in prolactin (PRL) and PRL receptor (PRLR) genes in relation to plasma prolactin levels and breast cancer risk: the multiethnic cohort (Abstract). BMC Med Genet 8: 72, 2007.

26. Matzuk MM, Kumar TR, Shou W, Coerver KA, Lau AL, Behringer RR, Finegold MJ. Transgenic models to study the roles of inhibins and activins in reproduction, oncogenesis, and development. Recent Prog Horm Res 51: 123-154, 1996.

27. Mitani F, Mukai K, Miyamoto H, Suematsu M, Ishimura Y. The undifferentiated cell zone is a stem cell zone in adult rat adrenal cortex. Biochim Biophys Acta 1619: 317-324, 2003.

28. Morishige WK, Rothchild I. Temporal aspects of the regulation of corpus luteum function by luteinizing hormone, prolactin and placental luteotrophin during the first half of pregnancy in the rat. Endocrinology 95: 260-274, 1974.

29. Ormandy CJ, Camus A, Barra J, Damotte D, Lucas B, Buteau H, Edery M, Brousse N, Babinet C, Binart N, Kelly PA. Null mutation of the prolactin receptor gene produces multiple reproductive defects in the mouse. Genes Dev 11: 167-178, 1997.

30. Ormandy CJ, Hall RE, Manning DL, Robertson JF, Blamey RW, Kelly PA, Nicholson RI, Sutherland RL. Coexpression and crossregulation of the prolactin receptor and sex steroid hormone receptors in breast cancer. J Clin Endocrinol Metab 82: 3692-3699, 1997.

31. Ormandy CJ, Binart N, Helloco C, Kelly PA. Mouse prolactin receptor gene: genomic organization reveals alternative promoter usage and generation of isoforms via alternative $3^{\prime}$-exon splicing. DNA Cell Biol 17: 761-770, 1998.

32. Peltoketo H, Rivero-Müller A, Ahtiainen P, Poutanen M, Huhtaniemi I. Consequences of genetic manipulations of gonadotrophins and gonadotrophin receptors in mice. Ann Endocrinol (Paris) 71: 170-176, 2010.

33. Polan ML, Laufer N, Dlugi AM, Tarlatzis BC, Haseltine FP, DeCherney AH, Behrman HR. Human chorionic gonadotropin and prolactin modulation of early luteal function and luteinizing hormone receptor-binding activity in cultured human granulosa-luteal cells. J Clin Endocrinol Metab 59: 773-779, 1984.

34. Rasmussen LM, Frederiksen KS, Din N, Galsgaard E, Christensen L, Berchtold MW, Panina S. Prolactin and oestrogen synergistically regulate gene expression and proliferation of breast cancer cells. Endocr Relat Cancer 17: 809-822, 2010. 
35. Ratner LD, Gonzalez B, Ahtiainen P, Di Giorgio NP, Poutanen M, Calandra RS, Huhtaniemi IT, Rulli SB. Short-term pharmacological suppression of the hyperprolactinemia of infertile hCG-overproducing female mice persistently restores their fertility. Endocrinology 153: 5980 5892, 2012.

36. Rilianawati Paukku T, Kero J, Zhang FP, Rahman N, Kananen K, Huhtaniemi I. Direct luteinizing hormone action triggers adrenocortical tumorigenesis in castrated mice transgenic for the murine inhibin alphasubunit promoter/simian virus $40 \mathrm{~T}$-antigen fusion gene. Mol Endocrinol 12: 801-809, 1998.

37. Rothchild I, Pepe GJ, Morishige WK. Factors affecting the dependency of $\mathrm{LH}$ in the regulation of corpus luteum progesterone secretion in the rat. Endocrinology 95: 280-288, 1974.

38. Rulli SB, Kuorelahti A, Karaer O, Pelliniemi LJ, Poutanen M, Huhtaniemi I. Reproductive disturbances, pituitary lactotrope adenomas, and mammary gland tumors in transgenic female mice producing high levels of human chorionic gonadotropin. Endocrinology 143: 4084-4095, 2002.

39. Rulli SB, Ahtiainen P, Mäkelä S, Toppari J, Poutanen M, Huhtaniemi I. Elevated steroidogenesis, defective reproductive organs, and infertility in transgenic male mice overexpressing human chorionic gonadotropin. Endocrinology 144: 4980-4990, 2003.

40. Schuff KG, Hentges ST, Kelly MA, Binart N, Kelly PA, Iuvone PM, Asa SL, Low MJ. Lack of prolactin receptor signaling in mice results in lactotroph proliferation and prolactinomas by dopamine-dependent and -independent mechanisms. J Clin Invest 110: 973-981, 2002.

41. Segaloff DL, Wang HY, Richards JS. Hormonal regulation of luteinizing hormone/chorionic gonadotropin receptor mRNA in rat ovarian cells during follicular development and luteinization. Mol Endocrinol 4: 1856$1865,1990$.

42. Stocco C, Telleria C, Gibori G. The Molecular Control of Corpus Luteum Formation, Function and Regression. Endocr Rev 28: 117-149, 2007.

43. Vaclavicek A, Hemminki K, Bartram CR, Wagner K, Wappenschmidt B, Meindl A, Schmutzler RK, Klaes R, Untch M, Burwinkel B, Försti A. Association of prolactin and its receptor gene regions with familial breast cancer. J Clin Endocrinol Metab 91: 1513-1519, 2006.

44. Viengchareun S, Servel N, Feve B, Freemark M, Lombes M, Binart N. Prolactin receptor signaling is essential for perinatal brown adipocyte function: a role for insulin-like growth factor-2. PLoS ONE 3: e1535, 2008.

45. Vomachka AJ, Pratt SL, Lockefeer JA, Horseman ND. Prolactin gene-disruption arrests mammary gland development and retards T-antigen-induced tumor growth. Oncogene 19: 1077-1084, 2000.

46. Wennbo H, Gebre-Medhin M, Gritli-Linde A, Ohlsson C, Isaksson OG, Tornell J. Activation of the prolactin receptor but not the growth hormone receptor is important for induction of mammary tumors in transgenic mice. J Clin Invest 100: 2744-2751, 1997.

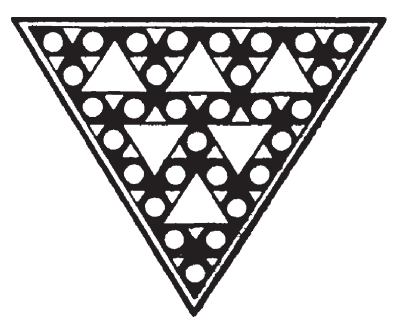

